\title{
Animal welfare in Italy from unification to the XXI century: a recent book on the subject
}

\author{
F Morganti ${ }^{1}$ \\ ${ }^{1}$ Laboratorio Analisi Politiche e Sociali (LAPS), LUISS Guido Carli, Roma
}

submitted: Mar 26, 2019, accepted: Mar 26, 2019, EPub Ahead of Print: Apr 1, 2019, published: Jul 7, 2019

DOI: 10.24019/jtavr.62 - Corresponding author:Dr. Federico Morganti, federico.morganti@gmail.com

(C) 2018 Fondazione Vasculab impresa sociale ONLUS. All rights reserved.

Human concern for animal welfare - including animalist thinking, animal rights activism, veganism, and vegetarianism - has become more widespread across the western world today than it has ever been. Of course, this phenomenon did not spring out of nothing; it has a history that dates back at least to the XIX century. Thanks to the wealth made possible by the industrial revolution, at least some animals (not only pets, but also those involved in economic production) were no longer (or not always) seen as mere goods for consumption, but possessors of a subjectivity - intelligence, emotions and, more fundamentally, the ability to perceive pain and pleasure, and thus worthy of protection. Before industrial revolution and the growth of national income in the Western world, not only were pets a luxury that most people could not afford, but the idea of protecting "animal welfare" when people could barely meet their everyday needs was much more problematic.

Besides, it was the XIX century that saw the introduction of the first forms of intensive farming, which began to raise ethical issues on the practice of meat consumption. In addition to this, the increasing circulation of Darwinism undoubtedly contributed to this transition because it promoted the image of non-human animals as fellow travelers resembling mankind in more aspects than once suspected.

The book La protezione degli animali in Italia. Storia dell'ENPA e dei movimenti zoofili e animalisti dalla metà dell'Ottocento alle soglie del Duemila ${ }^{1}$ by Andrea Maori, deals with the history of animal protection in Italy by focusing on the one Italian institution that represented the battle for a more humane treatment of non-humans and, ultimately, for the advocacy of animal rights: namely, Ente nazionale per la protezione degli animali (ENPA, "National Board for the Animal Protection").

The book itself was issued by ENPA publishing press. Regardless of the publisher's interest in the subject, the choice of ENPA as focus for a history of animal protection in Italy would still be perfectly legitimate. ENPA is in fact the oldest Italian organization for the protection of animals, and its history is inextricably intertwined with that of many other relevant animalist and "zoophile" associations, while it also influenced policy decisions on the subject over the years.

In the first chapters we learn how the Italian interest in the subject of animal welfare - even before unification (1861) - developed more or less during the same decades as in many other developed countries. In XIX century England paved the way, by promulgating the first legislative acts to regulate cruelty to animals, and thanks to the proliferation of publications and associations dedicated to the protection of animal welfare. The most important of these associations, the Society for the Prevention of Cruelty to Animals (founded in 1824), was later to obtain patronage from the crown and to become Royal Society in 1840. Soon France, Germany, Austria, Netherlands, Belgium, Switzerland and the United States would follow the same steps.

The first law against the mistreatment of animals was introduced in the Italian penal code in 1889, which imposed fines on those at fault of "unnecessary abuse" toward animals. As Maori suggests, the word "unnecessary" introduced a certain margin of discretionality to the judiciary because the boundaries of "necessary" infliction 
were left undefined. But more important is the question of why the government felt it was time to crack down on animal mistreatment.

With a clearly anthropocentric outlook, far from considering the point of view of the suffering animals, the legislator implied that all unnecessary infliction of pain to animals was at odds with "any sense of humanity, of compassion, of benevolence" in the perpetrator. In other words, what mattered was the human's feeling when mistreating the unfortunate animal, rather than the feeling of pain in the animals themselves. As the book repeatedly makes clear, all legislative acts in defence of animals up to the third quarter of the XX century would preserve more or less this same spirit. The decades preceding the introduction of the law had witnessed the birth of many early protectionist associations in several Italian municipalities, but with little success, both in terms of public appreciation and results. One of these associations, Società Torinese Protettrice degli Animali ("Turin Society for Animal Protection", founded in 1871) was later to develop into what we know today as ENPA.

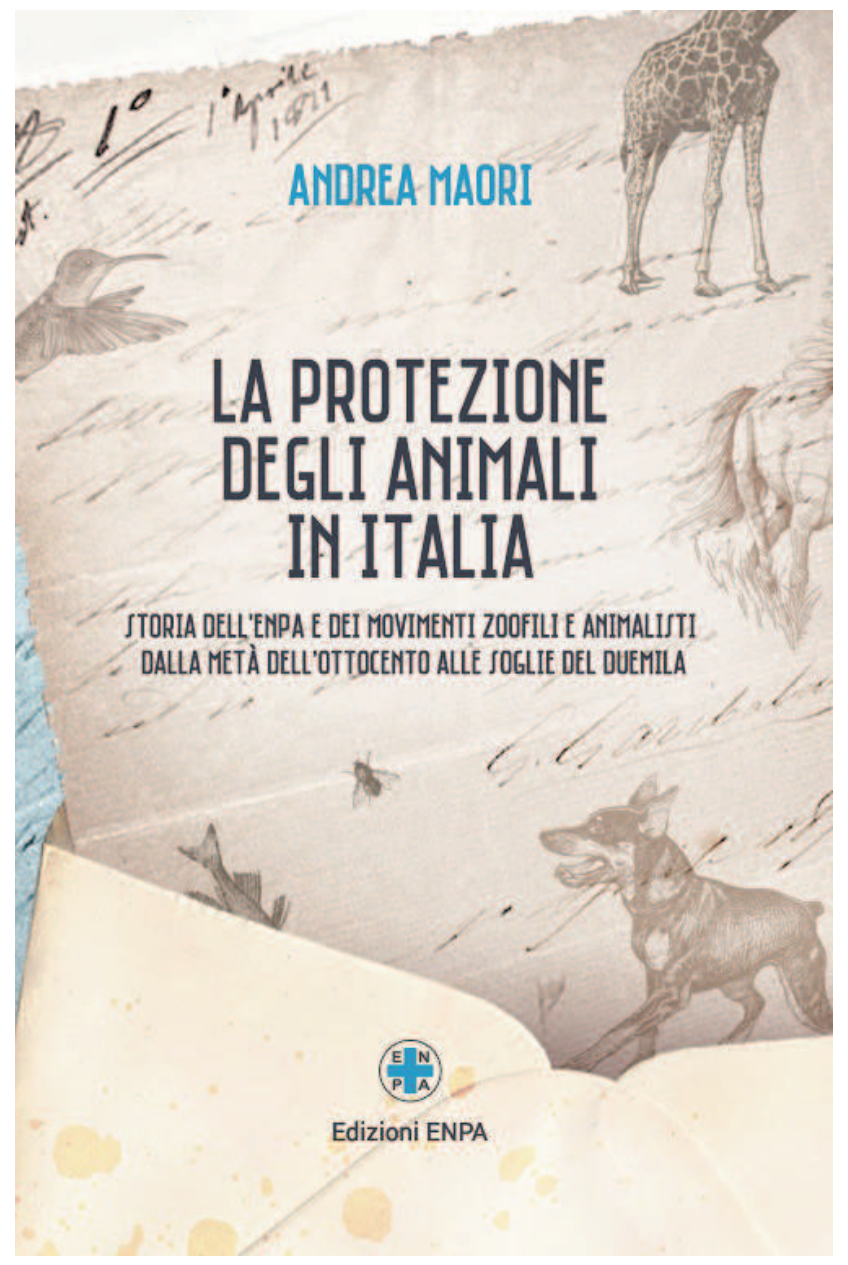

Animal Welfare in Italy. ENPA Ed., Roma 2016.
This organization was actively involved in ensuring public hygiene, raising awareness among the public opinion, ensuring the enforcement of existing laws, and lobbying for more incisive ones - in addition to supervising the practice of animal experimentation (then referred to as "vivisection") in universities and research labs. Yet there was not much success these societies could achieve by occasionally reporting infractions to the authorities. In general, the rise of these organizations and the development of the laws approved by the Parliament would prove very difficult to enforce, despite all the efforts. Not even those associations who had been granted the title of Ente Morale ("Moral Association") - i.e. patronage by the crown - could employ their officers as public servants, and they were thus devoid of any authority of giving fines, let alone arresting the infractor.

In 1913 the Italian Parliament voted for what is now remembered as "Legge Luzzatti" (named after Luigi Luzzatti, former Prime Minister and promoter of the bill). The bill confirmed the concept of "unnecessary torture", thus fundamentally replicating the spirit of the former jurisprudence on the subject. More importantly, it strengthened the function of the officers employed by zoophile societies, who could now be granted the status of agenti di pubblica sicurezza ("Public Security Officers"). The bill also touched upon the thorny issue of vivisection, which it considered a "lesser evil" - i.e. a necessary instrument for scientific researchers, which was allowed, provided that it was solely performed by accredited "experts" (i.e. physicians or veterinarians). This point in particular stimulated a heated debate between animalist groups who demanded more restrictive protections of animals versus the researchers, physicians, and medical practitioners, who questioned such limitations as a de facto state monopoly on science and thus an infringement of freedom of research.

The efforts of protectionist societies was halted by the outbreak of World War I, as resources were redirected from civil society to military purposes. At this point, all protectionist societies scattered across the country were deprived of any sort of top-down coordination or long-term strategy, and their financial resources were limited. The situation changed under the Fascist regime, first thanks to the foundation of Federazione nazionale fra le Società zoofile ("National Federation of Zoophile Societies") in 1929, and then, more radically, with the institution of ENFPA, Ente Nazionale Fascista per la Protezione degli Animali ("National Fascist Board for the Animal Protection"). All zoophile and protectionist organizations, and the National Federation itself, were at once suppressed, and their offices and duties fell under direct control and authority on ENFPA. The Fascist press emphasised respect toward animals as a civic duty, overtly denying that tenderness to animals could corrode

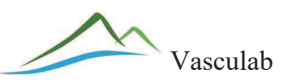


or weaken the "warrior spirit" of the nation. There was no sentimentalism in the protection of local fauna, which conversely constituted a unique and valuable treasure of the country. "He who mistreats animals", put it bluntly by the Minister of Education Giuseppe Bottai, "cannot call himself Italian". Hunting, on the other hand, was granted its status as "economic, sport, and military activity of the Nation".

The same bill which proclaimed the constitution of ENFPA confirmed the status of Public Servants to its officers, who were to be authorized by the Ministry of Interior and were fully equipped with guns and rifles. These officers could supervise that animal experimentation in labs was performed according to the existing laws. Among other accomplishments of the fascist era, they promoted the adoption of a gun, fabricated by ENFPA, for more humane technique of slaughter (which they hope to make mandatory).

In the aftermath of World War II, after the Treasury gave its approval to the permanence of a national organization for animal welfare - the newly-renamed ENPA continued to operate more or less according to the same guidelines hitherto followed. The following years saw a growth in public awareness concerning issues of animal welfare, thanks to an increasing attention by the press, and of particular importance was the National TV Broadcast (Rai) dedicating some space to the topic. New organizations were born between '50s and '60s, such as Lega Italiana per la Protezione degli Animali ("Italian League for the Protection of Animals") and the first vegetarian society (i.e. Società Vegetariana Italiana), all relying on ENPA's activity as their benchmark.

The appearance of the first Italian Vegetarian Society (1952) introduced into public debate the idea of "animal rights", which gained increasing momentum in the following decades. The law instituting the National Health Service (1978) assigned a major role to veterinarians with regard to public hygiene as related to animals, and zootechnical economic activity in particular. But it was ENPA that provided funds and instruments to help slaughterhouses comply with the law and thus limit unnecessary infliction of pain to livestocks. Of course, the evaluation of what counted as necessary or unnecessary pain could differ, which caused a number of misunderstandings between ENPA and local municipalities (e.g. in the event of local fairs and festival, where animals could be employed for entertaining purposes).

In 1979, under the initiative of the government chaired by Giulio Andreotti and with the approval of the President of the Republic Sandro Pertini, ENPA was finally privatized, even though it had recently survived a bill that was meant to cut a number of "useless" public organizations. From then on, it ceased to be under the supervision of the Ministry of Interior, and their officers were no longer "public servants". Due to an increasing attention to animal rights, after being privatized ENPA found new energy, and intensified its activity of demanding more effective laws in terms of animal protection. Also, the philosophy of animal welfare found a new alliance in the growing environmental movement, in so far as associations of the likes of WWF (World Wildlife Fund) demanded political action for protection of endangered species.

As an explanation for the growing concern for animals among the public, Maori suggests that some credit is to be given to the spread of naturalistic photography and periodicals such as National Geographic (or Airone, in Italy) and documentaries (most notably by Piero Angela), which made nature and non-human animals no longer a subject solely for experts and activists, but a topic of discussion for laymen and households. Over the last decades, the Italian Parliament has approved several laws of interest for those concerned about animal welfare, which Maori describes at length in the last part of the book. The most important is the one promulgated in 2004, which stipulated that several kinds of animal mistreatment (e.g. torture, animal fights) were punishable as felonies.

Over the last decades, the Italian Parliament has approved several laws of interest for those concerned about animal welfare, which Maori describes at length in the last part of the book. The most important is the one promulgated in 2004, which stipulated that several kinds of animal mistreatment (e.g. torture, animal fights) were punishable as felonies.

In the author's view, the bill - while more advanced than previous laws on the subject - can still be criticized under at least two respects. First, it fails to sanction any involuntary inflictions of pain to animals, and second, it is far from granting animals with a status as bearers of rights. At the same time, Maori accepts the point made by jurist Francesco Maria Agnoli, that "such recognition would have implied a copernican revolution in Italian juridical system [...] with relevant consequences that should be put to effect only on the basis of a wide social consensus, which at the time was lacking".

Despite the potential bias of both the author and the publisher towards the subject of the study, La protezione animale in Italia fairly stands as a thorough and instructive reading, which compared to the existing literature is probably unparalleled as to completion of information (not always depth of analysis). The last part of the book noteworthily gathers a number of relevant documents, acts, and speeches - discussed at length in the first part of the book - which are related the development of animalist movements and societies throughout history. 
F Morganti - Animal welfare in Italy from unification to the XXI century: a recent book on the subject

\section{References}

1) Maori A. La protezione degli animali in Italia. Storia dell'ENPA e dei movimenti zoofili e animalisti dalla metà dell'Ottocento alle soglie del Duemila [Animal Welfare in Italy. The

history of ENPA and of Zoophile and Animalist Societies from the MidNineteenth Century to the Dawn of the New Millennium]. ENPA Ed., Roma 2016. 